\section{(2) OPEN ACCESS}

\title{
Assessment of mismatch repair deficiency in ovarian cancer
}

\author{
Emma J Crosbie (1) , ${ }^{1,2}$ Neil A J Ryan, ${ }^{1,2,3}$ Rhona J McVey, ${ }^{4}$ Fiona Lalloo, ${ }^{5}$ \\ Naomi Bowers, ${ }^{5}$ Kate Green, ${ }^{5}$ Emma R Woodward (1) ${ }^{3,5}$ Tara Clancy, ${ }^{5}$ James Bolton, ${ }^{4}$ \\ Andrew J Wallace, ${ }^{5}$ Raymond F McMahon, ${ }^{4}$ D Gareth Evans (1) 3,5
}

${ }^{1}$ Division of Cancer Sciences, The University of Manchester, Manchester M13 9WL, UK ${ }^{2}$ Department of Obstetrics and Gynaecology, St Mary's Hospital, Manchester University NHS Foundation Trust, Manchester Academic Health Science Centre, Manchester M13 9WL, UK

${ }^{3}$ Division of Evolution and Genomic Medicine, The University of Manchester, Manchester M13 9WL, UK ${ }^{4}$ Department of Pathology, Manchester University NHS Foundation Trust, Manchester Academic Health Science Centre, Manchester M13 9WL, UK

${ }^{5}$ Manchester Centre for Genomic Medicine, North-West Genomics Laboratory Hub, Manchester University NHS Foundation Trust, Manchester Academic Health Science Centre, Manchester M13 9WL, UK

\section{Correspondence to}

Prof Emma J Crosbie, Division of Cancer Sciences, The University of Manchester, St Mary's Hospital, 5th floor- Research, Oxford Road, Manchester M13 9WL, UK:

emma.crosbie@manchester. ac.uk

Received 15 June 2020 Revised 25 July 2020 Accepted 27 July 2020

Check for updates

(c) Author(s) (or their employer(s)) 2020. Re-use permitted under CC BY. Published by BMJ.

To cite: Crosbie EJ, Ryan NAJ, McVey RJ, et al. $\checkmark$ Med Genet Epub ahead of print: [please include Day Month Year]. doi:10.1136/ jmedgenet-2020-107270

\section{ABSTRACT}

Background Hereditary causes of ovarian cancer include Lynch syndrome, which is due to inherited pathogenic variants affecting one of the four mismatch repair genes involved in DNA repair. The aim of this study was to evaluate tumour mismatch repair deficiency and prevalence of Lynch syndrome in high-risk women referred to the Manchester Centre for Genomic Medicine with ovarian cancer over the past 20 years.

Methods Women with ovarian cancer diagnosed before the age of 35 years and/or with a suggestive personal or family history of Lynch syndrome cancers underwent tumour testing with immunohistochemistry for mismatch repair deficiency and, where indicated, MLH1 promoter methylation testing followed by constitutional testing for Lynch syndrome.

Results In total, 261 ovarian cancers were tested and $27(10.3 \% ; 95 \% \mathrm{Cl} 6.9 \%$ to $14.7 \%)$ showed mismatch repair deficiency by immunohistochemistry. Three of 7 with MLH1 loss showed MLH1 promoter hypermethylation, and 18 of the remaining 24 underwent constitutional testing for Lynch syndrome. A further 15 women with mismatch repair proficient tumours underwent constitutional testing because of a strong family history of Lynch syndrome cancers. Pathogenic variants were identified in 9/33 (27\%) women who underwent constitutional testing, aged 3359 years (median 48 years), including one whose tumour was mismatch repair proficient. Most Lynch syndrome tumours were of endometrioid histological subtype.

Conclusions Tumour mismatch repair deficiency identified by immunohistochemistry is a useful prescreen for constitutional testing in women with ovarian cancer with personal or family histories suggestive of Lynch syndrome.

\section{INTRODUCTION}

Ovarian cancer is the seventh most common malignancy worldwide and the most lethal gynaecological cancer. ${ }^{1-3}$ Epithelial ovarian cancer is one of the most heritable malignancies, frequently due to pathogenic variants in single high-risk genes. The heritable component of ovarian cancer is predominantly due to constitutional pathogenic variants in BRCA1 and BRCA2 with as many as $22 \%$ of women with high grade serous ovarian cancers (HGSOC) carrying pathogenic variants in these genes. ${ }^{4}$ The other leading heritable cause is Lynch syndrome (LS), an inherited mismatch repair (MMR) deficiency due to constitutional pathogenic variants affecting one of the four MMR genes, MSH2, MLH1, MSH6 and PMS2. ${ }^{5}$ Around 1:280 of the general population carries a pathogenic variant in a MMR gene, the great majority of whom are undiagnosed. ${ }^{6}$ Women heterozygous for pathogenic MMR gene variants have a 3\%-17\% lifetime risk of ovarian cancer, and higher risks for colorectal and endometrial cancers. ${ }^{78}$

Since the discovery of the MMR genes in 1993-1994, clinicians have tried to target constitutional testing for LS to those at highest risk. The Amsterdam criteria were developed in $1991,{ }^{9}$ but these require a strong family history of colorectal cancer to be discriminatory. Even adding additional LS tumours to the criteria, such as endometrial and ovarian cancer ${ }^{10}$ has added little to its detection rate $^{11}$ or sensitivity. ${ }^{13}$ Testing for LS outside of the Amsterdam criteria, ${ }^{9}{ }^{10}$ where upfront constitutional testing is practised, has largely depended on a prescreen of the incident tumour using immunohistochemistry (IHC) for MMR protein expression or DNA for microsatellite instability (MSI). ${ }^{12}$ There have been very few studies that have looked at the success of this prescreen in ovarian cancer and most have included small numbers of tumours and have concentrated on just one histological subtype of ovarian cancer (endometrioid). ${ }^{13} 14$ This ignores the fact that restricting testing based on histological subtype misses cases of LS, particularly as morphology is subjective and can be challenging in complex cases. ${ }^{1516}$

We have evaluated our prescreening strategy with IHC in women referred to the regional genetics department with possible LS-associated ovarian cancer from 2000 to 2020 and assessed the identification of constitutional MMR pathogenic variants.

\section{METHODS \\ Participants}

Women referred to the regional genetics department in Manchester with ovarian cancer and concerns about the possibility of LS provided consent for tumour and if indicated constitutional testing. Most women had a history of another LS-related cancer in themselves or another family member (colorectal, endometrial, ovary, biliary tree, urinary tract, gastric or skin). However, some were selected based on diagnosis at $<35$ years of age. 


\section{Immunohistochemistry}

IHC for the four MMR proteins was performed in the clinical pathology laboratory using the automated Ventana BenchMark ULTRA IHCISH staining module and the OptiView, 3'diaminobenzidine V.5 detection system (Ventana, USA) according to standard clinical protocols. Tumour epithelial MMR expression was scored by two expert independent observers using stroma as internal control and as described previously. ${ }^{17}$

\section{Methylation analysis}

Reflex MLH1 promoter methylation testing was performed on tumours showing loss of MLH1 on IHC. Extracted DNA was bisulfite converted and then amplified with bisulfite specific primers in triplicate. A region of the MLH1 promoter containing four $\mathrm{CpG}$ dinucleotides whose methylation status is strongly correlated with MLH1 expression were sequenced using a pyrosequencer (PSQ 96MA). Two independent scientists interpreted the pyrograms. 'Hypermethylation' was described as $>10 \%$ mean methylation across the four $\mathrm{CpG}$ dinucleotides on a minimum of two of three replicate analyses. In addition to promoter methylation analysis, testing was carried out for the $B R A F$ c. $1799 \mathrm{~T}>\mathrm{A}$ variant in some cases.

\section{Microsatellite instability analysis}

Extracted DNA underwent sodium bisulfite conversion using the Epitect Plus FFPE kit (Qiagen, UK). The MSI analysis system V.1.2 (Promega, USA) used fluorescent-labelled primers to coamplify seven markers, including five mononucleotide-repeat markers (BAT-25, BAT-26, NR-21, NR-24 and MONO-27), and two control penta-nucleotide-repeat markers (Penta-C/Penta-D). MSI status was reported as microsatellite stable (MSS) where all five mononucleotide loci between tumour and matched normal tissue were identical; MSI-low (MSI-L) where there was discordance in one mononucleotide locus and MSI-high (MSI-H) where two or more mononucleotide loci were discordant.

\section{Constitutional analysis}

DNA was extracted from 2 to $5 \mathrm{~mL}$ lymphocyte blood (EDTA anticoagulant) using Chemagic DNA blood chemistry (CMG-1097-D) on an automated Perkin Elmer Chemagic 360 Magnetic Separation Module and a JANUS Integrator 4-tip Automated Liquid handling platform. DNA was eluted into $400 \mathrm{uL}$ buffer. Extracted DNA samples were measured for DNA yield, concentration and quality using a Nanodrop ND-8000 spectrophotometer. Three MMR genes MLH1, MSH2 and MSH6 were amplified using long range PCR followed by next generation sequencing using Illumina SBS v2 $2 \times 150$ bp chemistry on an Illumina MiSeq. The whole coding region, intronic flanking sequences to $\pm 15 \mathrm{bp}$ and known splicing variants of MLH1, MSH2 and MSH6 were analysed (minimum 100x coverage depth). Variant identification and calling was via an in-house bioinformatic pipeline. Reported sequence changes and regions with $<100 \times$ coverage were retested via Sanger sequencing using BigDye V.3.1 chemistry. Copy number analysis to detect large genomic rearrangements affecting the three MMR genes was performed using MLPA MRC-Holland probe mixes: P003-D1 MLH1/MSH2 and P072-C1 MSH6. Variant nomenclature followed Human Genome Variation Society guidelines (http:// www.hgvs.org/vamomen) using reference sequences: LRG_216, t1(MLH1); LRG_218, t1(MSH2); LRG 219, t1(MSH6). Exons were numbered consecutively starting from exon 1 as the first translated exon for each probe mix. Cases with PMS2 protein loss, normal MLH1 methylation and no path_MLH1/MSH2/MSH6 variant underwent path_PMS2 analysis at the regional specialist Yorkshire and North East Genomic Laboratory.

All women gave written informed consent for tumour and blood testing except deceased cases, whose tumour was obtained and tested with a relative's consent. Advice from our ethics committee was that the current analysis represented clinical service evaluation and that no specific ethics application was required. There is no directly identifiable patient information presented.

\section{Statistics}

Differences between values were tested by a two-tailed Fisher's $\chi^{2}$ test.

\section{RESULTS}

In total, 261 women with ovarian cancer underwent an IHC prescreen for LS (table 1, figure 1). They were aged between 16 and 89 years (median $=49$ years). Fifty-one cases were tested because they were diagnosed at $<35$ years of age. All histological subtypes were tested if indicated, with HGSOC the most frequently tested. Overall, only $27(10.3 \%$; $95 \%$ CI $6.9 \%$ to 14.7\%) tumours showed MMR deficiency by IHC with just 7 (2.7\%) having loss of MLH1 (table 2). Three of these tumours showed MLH1 promotor hypermethylation and therefore constitutional LS testing was not performed. Eighteen of the remaining 24 women whose tumours showed MMR deficiency underwent constitutional testing for MMR pathogenic variants. The

Table 1 Number of ovarian cancers tested for IHC by pathology and proportion of women with MMR pathogenic variants

\begin{tabular}{|c|c|c|c|c|c|c|c|c|c|c|c|c|c|}
\hline Pathology & Tested (n) & $\begin{array}{l}\text { IHC loss } \\
\text { (n) }\end{array}$ & $\begin{array}{l}\text { IHC loss } \\
(\%)\end{array}$ & $\begin{array}{l}\text { BRAF } \\
\text { tested } \\
\text { (n) }\end{array}$ & $\begin{array}{l}\text { C.1799T>A } \\
\text { positive } \\
\text { (n) }\end{array}$ & $\begin{array}{l}\text { C.1799T >A } \\
\text { positive } \\
\text { (\%) }\end{array}$ & $\begin{array}{l}\text { Methylation } \\
\text { tested (n) }\end{array}$ & $\begin{array}{l}\text { Hypermethylated } \\
\text { (n) }\end{array}$ & $\begin{array}{l}\text { Hypermethylated } \\
(\%)\end{array}$ & $\begin{array}{l}\text { Tested for } \\
\text { path_MMR } \\
\text { (n) }\end{array}$ & $\begin{array}{l}\text { Lynch } \\
\text { syndrome } \\
\text { (n) }\end{array}$ & \multicolumn{2}{|c|}{$\begin{array}{l}\text { Lynch syndrome } \\
(\%)\end{array}$} \\
\hline Endometrioid & 43 & 9 & 20.9 & 2 & 0 & 0 & 4 & 2 & 50 & 10 & 4 & 40 & $\begin{array}{l}\text { MSH2, } \\
3 \text { MSH6 }\end{array}$ \\
\hline Clear cell & 19 & 2 & 10.5 & 0 & - & - & 0 & - & - & 4 & 2 & 50 & MLH1, MSH2 \\
\hline Mucinous & 59 & 6 & 10.2 & 1 & 0 & 0 & 1 & 0 & 0 & 10 & 0 & 0 & - \\
\hline Low grade serous & 10 & 0 & 0 & 0 & - & - & 0 & - & - & 0 & 0 & 0 & - \\
\hline High grade serous & 79 & 6 & 7.6 & 1 & 0 & 0 & 1 & 0 & 0 & 9 & 2 & 22 & MSH2, MSH6 \\
\hline $\begin{array}{l}\text { Adenocarcinoma } \\
\text { (other) }\end{array}$ & 38 & 3 & 7.9 & 1 & 0 & 0 & 1 & 1 & 100 & 2 & 0 & 0 & - \\
\hline Other* & 13 & 1 & 7.7 & 0 & - & - & 0 & - & - & $1+$ & 1 & 100 & MSH2 \\
\hline Total & 261 & 27 & 10.3 & 5 & 0 & 0 & 7 & 3 & 43 & 36 & 9 & 25 & $\begin{array}{l}4 M S H 6,4 \\
M S H 2,1 \\
M L H 1\end{array}$ \\
\hline
\end{tabular}




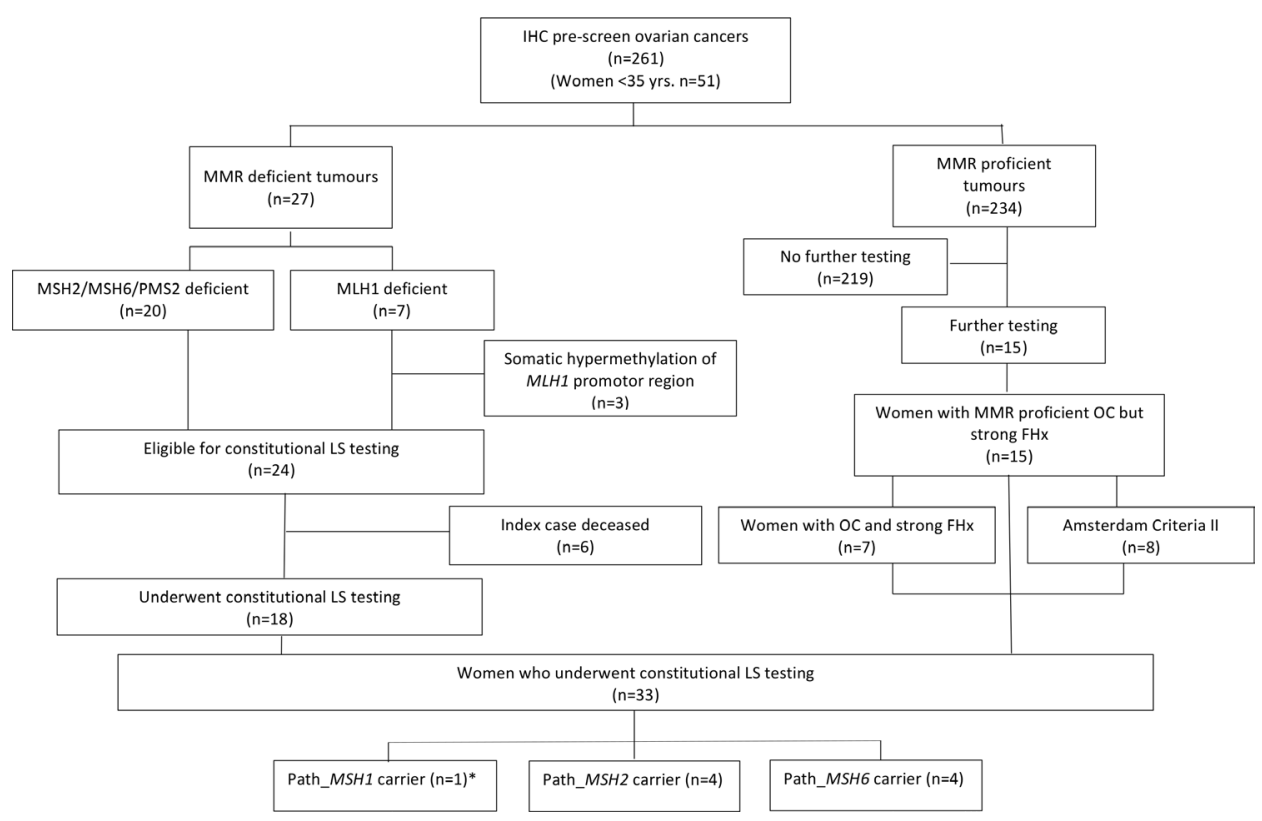

Figure 1 Study flow diagram. *Includes LS carrier found in a MMR proficient case with a simultaneous constitutional pathogenic variant in BRCA 1. FHx, family history; IHC, immunohistochemistry; MMR, mismatch repair; LS, Lynch syndrome; OC, ovarian cancer.

remaining six did not undergo constitutional analysis because the ovarian cancer case was deceased and a blood lymphocyte sample was not available. An additional 15 women underwent constitutional analysis despite having MMR proficient tumours due to a strong family history, with eight meeting Amsterdam II criteria $^{9}$ (figure 1).

MSI testing was performed for 24/261 cases. Five tumours were MSI-H, all of which were MMR deficient by IHC and $4 / 5$ women underwent constitutional analysis for MMR pathogenic variants. Two tumours were MSI-L and MMR deficient, and one out of two of these women underwent constitutional analysis. Seventeen tumours were MSS, six of which were MMR deficient and five of these six women underwent constitutional analysis for MMR pathogenic variants. Four of six path_MMR carriers had MSI-H tumours; one was MSI-L (MSH2), one MSS (MSH6) and the remaining three were not MSI tested (table 3).

MMR pathogenic variants were found in 9/33 (27\%) women who underwent constitutional testing with ages of ovarian cancer diagnosis of 33-59 years (median 48) (table 3). The highest rate was for endometrioid ovarian cancer with 10/43 (9.6\%) having a constitutional MMR pathogenic variant. The only LS case whose ovarian tumour was MMR proficient was a patient with a clear cell carcinoma who also had a constitutional
BRCA1 pathogenic variant. It is therefore likely her ovarian cancer was not driven by her $M L H 1$ pathogenic variant. There were four pathogenic variants each in MSH2 and MSH6, the MSH6 cases only displayed MSH6 IHC loss whereas three of the MSH2 pathogenic variants had loss of both MSH2 and MSH6. Selection for ovarian cancer by age $<35$ years was not effective as a selection tool as only $4 / 52(7.7 \%)$ had IHC loss. Only one of the four women $<35$ years tested for constitutional pathogenic variants had a path MMR variant identified, and that patient had a parent with four separate bowel primary tumours highly suggestive of LS (table 3).

\section{DISCUSSION}

Here, we describe our 20-year experience of tumour MMR IHC as a prescreen for constitutional testing women with suspected LS-associated ovarian cancer. We tested 261 ovarian tumours for MMR deficiency because women were diagnosed $<35$ years of age and/or because they had a suggestive personal or family history of LS. Those with strong clinical risk factors underwent constitutional testing even if their tumours were MMR proficient. In total, 27 tumours (10.3\%) were MMR deficient and 8 of these had LS. Most were of endometrioid histological subtype.

Table 2 IHC loss and constitutional MMR pathogenic variant detection rates in all index ovarian cases tested

\begin{tabular}{lllllll}
\hline & Tested $(\mathbf{n})$ & IHC loss $(\mathbf{n})$ & IHC loss $(\%)$ & Tested for path_MMR $(\mathbf{n})$ & Lynch syndrome (n) & Lynch syndrome (\%) \\
\hline Any loss & 261 & 27 & 10.3 & 18 & 8 & 44.4 \\
MLH1 loss & 261 & 7 & 2.7 & 3 & 0 & 0.0 \\
Either MSH2 or MSH6 & 261 & 19 & 7.3 & 15 & 8 & 53.3 \\
MSH2 loss & 261 & 13 & 4.9 & 9 & 4 & 44.4 \\
MSH6 loss & 261 & 10 & 3.8 & 9 & 6 & 66.7 \\
MSH6 loss alone & 261 & 7 & 2.7 & 6 & 4 & 66.7 \\
PMS2 loss alone & 261 & 0 & 0.0 & 0 & 0 & - \\
No Loss & 234 & 0 & 0.0 & 15 & $1^{*}$ & 6.7 \\
\hline
\end{tabular}

*Ovarian clear cell carcinoma aged 59 years had exon 6-19 deletion of $M L H 1$ with normal IHC -family met Amsterdam II criteria. She also carries a BRCA1 exon 13 duplication. She developed grade 3 triple negative breast cancer at 71 and sebaceous carcinoma at 67 years.

IHC, immunohistochemistry; MMR, mismatch repair. 
Table 3 Ovarian cancer cases with Lynch syndrome

\begin{tabular}{|c|c|c|c|c|c|c|c|}
\hline Gene & $\begin{array}{l}\text { FIGO stage and histological } \\
\text { subtype }\end{array}$ & Age (years) & $\begin{array}{l}\text { IHC loss } \\
\text { ( } 4 \text { protein panel) }\end{array}$ & MSI & $\begin{array}{l}\text { Type of pathogenic } \\
\text { variant }\end{array}$ & Path_MMR variant & $\begin{array}{l}\text { Meets Amsterdam } \\
\text { criteria? }\end{array}$ \\
\hline MLH1 & Stage $1 \mathrm{c}$ clear cell & 59 & None & Not tested & Large rearrangement & MLH1 exon 6-19 deletion & $\begin{array}{l}\text { Yes-Amsterdam } \\
\text { modified }\end{array}$ \\
\hline MSH2 & $\begin{array}{l}\text { Stage 1a mixed endometrioid/ } \\
\text { clear cell }\end{array}$ & 34 & MSH2 loss & MSI-H & Splice site & MSH2 c. $1276+2 \mathrm{~T}>\mathrm{C}$ & No \\
\hline MSH2 & Stage $3 c$ high grade serous & 38 & MSH2 and MSH6 loss & MSI-L & Truncating & MSH2 c.528_529delTG & No \\
\hline MSH2 & Stage 1a carcinosarcoma & 48 & MSH2 and MSH6 Loss & MSI-H & Large rearrangement & MSH2 exon 3 deletion & No \\
\hline MSH2 & Stage 1c endometrioid & 51 & MSH2 and MSH6 loss & MSI-H & Truncating & MSH2 c.196delT & No \\
\hline MSH6 & Stage $1 \mathrm{a}$ endometrioid & 47 & MSH6 loss & Not tested & Splice site & MSH6 c.3439-1G>T & $\begin{array}{l}\text { Yes-Amsterdam } \\
\text { modified }\end{array}$ \\
\hline MSH6 & Stage 1 endometrioid & 50 & MSH6 loss & MSI-H & Missense & MSH6 c.1346T>C p.Leu449Pro & No \\
\hline MSH6 & Stage 2 high grade serous & 50 & MSH6 loss & MSI-S & Truncating & MSH6 c.3732_3735dupATTT & No \\
\hline MSH6 & $\begin{array}{l}\text { Stage } 3 c \text { poorly differentiated } \\
\text { endometrioid with focal } \\
\text { neuroendocrine features }\end{array}$ & 53 & MSH6 loss & Not tested & Truncating & MSH6 c.3261 delC & No \\
\hline
\end{tabular}

IHC, immunohistochemistry; MMR, mismatch repair.

One woman with constitutional path_MMR variant had a MMR proficient tumour; she also had a constitutional BRCA1 pathogenic variant. She is unlikely therefore to have developed ovarian cancer via a MMR driven pathway.

Previous studies examining the MMR status of unselected endometrioid or clear cell ovarian cancers found similar rates of MMR deficiency, but overall numbers were very small. ${ }^{13} 1418$ Two systematic reviews found that approximately $10 \%$ of ovarian tumours are MMR deficient by IHC, but included studies that were very limited with respect to their reporting of basic epidemiological, molecular and clinical features. ${ }^{19} 20$ There was also poor reporting of constitutional status. A recent study by Leskela et $a l^{21}$ examined the MMR status of 502 stage I/II tumours selected from the GEICO Early Stage Ovarian Cancer Registry. The authors report MMR deficiency in 18.7\% endometrioid and $2.4 \%$ clear cell tumours overall, but do not provide information about clinical risk factors for LS in their cohort. It is perhaps surprising that despite selecting for LS features, such as early age of cancer onset and indicative personal or family history, that detection rates were not higher in our study, with only $10.3 \%$ with IHC loss and $3.5 \%$ with a path_MMR variant. Age selection ( $<35$ years) was not an effective triage strategy for constitutional testing with only $7.7 \%$ IHC loss and $1.9 \%$ path_MMR. Furthermore, failure to select for pathology type by including serous histological subtypes will have further reduced our detection rates.

There are several strengths to our work. First, we carried out MMR IHC tumour prescreening for all women referred to the clinical genetics department whose age and family history were suggestive of LS-associated ovarian cancer. We did not restrict testing to any particular histological subtype. This is important because histological subtyping is subjective, challenging in difficult cases and has evolved considerably over the past 20 years, with validated IHC panels increasingly used to assist diagnosis. Many of our cases pre-dated the now gold standard expert gynaecological pathology review and confirmation by IHC. ${ }^{16}$ Restricting testing to endometrioid subtype would deny LS testing to women with ovarian cancer diagnosed and treated historically and in non-expert centres. In particular, women diagnosed with non-endometrioid tumours who have survived without recurrence from this earlier era may harbour a constitutional MMR pathogenic variant, as survival in LS is known to be good, and tumours may on review be reclassified with modern pathology. ${ }^{15}$ Second, we provide detailed clinical annotation for all proven LS-associated ovarian tumours as well as comprehensive molecular phenotyping, including MMR, MSI and, where indicated, $M L H-1$ promoter methylation status. Analyses were carried out to quality-assured clinical standards in specialist pathology and genetics referral laboratories. Data were collected from our prospective clinical database, ensuring comprehensive reporting of all cases and minimising issues with missing data. All non-deceased women with MMR deficient ovarian tumours unexplained by MLH1 promoter hypermethylation and 15 others, whose clinical risk factors were particularly suggestive, underwent definitive constitutional LS testing using blood lymphocyte DNA. This compares favourably with preceding series where the conversion to constitutional testing was poor and pathogenic variants were assumed from allele frequency in adjacent normal tissue. ${ }^{18-21}$ Third, we tested 15 women with strong clinical risk factors whose ovarian tumours were MMR proficient, facilitating an assessment of the accuracy of MMR IHC as a prescreen for LS constitutional testing, which is poorly reported in the literature. We found only one case of MMR proficient LS-associated ovarian cancer, in a woman who also carried a BRCA1 pathogenic variant and whose tumour is likely to have developed via a non MMR driven pathway.

Limitations of the study include failure to conduct MSI analysis for all cases, which precludes a direct comparison between MMR IHC and MSI status as a prescreen for constitutional LS testing. The single centre nature of this study is another limitation, since we cannot necessarily extrapolate our conclusions to other healthcare settings where clinical genetics referral criteria for suspected LS may differ. Our cohort was selected for IHC testing and downstream analyses based on clinical criteria and therefore may not reflect the MMR status of unselected ovarian cancer populations.

The emergence of targeted therapies has led to mainstream somatic and/or constitutional BRCA1/2 sequencing of women with ovarian cancer to inform suitability for PARP inhibitor therapy and clinical trial enrolment. ${ }^{22} 23$ Given the similar cumulative risk of ovarian cancer in LS to BRCA2, testing premenopausal women with epithelial ovarian cancer for both $B R C A 1 / 2$ and LS is appropriate, particularly in an era of panel gene testing where there is little additional cost to add more genes. ${ }^{24}$ If this practice becomes widespread, it may reduce the requirement for a prescreen for LS testing of patient with recently diagnosed ovarian cancer, although a prescreen would still be useful for women referred to clinical genetics departments with a previous history of ovarian cancer, in whom a priori panel gene somatic testing is unlikely to be indicated. 
In summary, we report our experience of MMR IHC as a prescreen for constitutional MMR pathogenic variant testing in women with clinical risk factors for LS-associated ovarian cancer. LS is rare if tumours are MMR proficient. While most LS-associated ovarian tumours are of endometrioid histological subtype, the subjective and sometimes challenging task of pathological interpretation risks misclassification. Thus, our practice is to continue to prescreen all ovarian tumours with clinical risk factors for LS irrespective of tumour histological subtype, especially if their tumour pre-dates recent multidisciplinary panel review in an expert centre.

Twitter Emma J Crosbie @ProfEmmaCrosbie, Neil A J Ryan @neilajryan and Emma RWoodward @ER_Woodward

Contributors DGE is the principal investigator for the study and its guarantor. EJC and DGE conceived the study. All authors contributed to data acquisition and interpretation. EJC and DGE wrote the first draft of the manuscript. All authors reviewed the manuscript and approved its final content.

Funding NAJR was a Doctoral Medical Research Council (MRC) Research Fellow (MR/M018431/1), DGE a National Institute for Health Research (NIHR) Senior Investigator (NF-SI-0513-10076), EJC a NIHR Clinician Scientist (NIHR-CS-012-009), and their work was supported through the NIHR Manchester Biomedical Research Centre (IS-BRC-1215-20007).

Disclaimer This article presents independent research funded by the NIHR and MRC. The views expressed are those of the authors and not necessarily those of the MRC, NHS, NIHR or the Department of Health.

Competing interests None declared.

Patient consent for publication Not required.

Provenance and peer review Not commissioned; externally peer reviewed.

Data availability statement Data are available from the corresponding author on reasonable request.

Open access This is an open access article distributed in accordance with the Creative Commons Attribution 4.0 Unported (CC BY 4.0) license, which permits others to copy, redistribute, remix, transform and build upon this work for any purpose, provided the original work is properly cited, a link to the licence is given, and indication of whether changes were made. See: https://creativecommons.org/ licenses/by/4.0/.

\section{ORCID iDs}

Emma J Crosbie http://orcid.org/0000-0003-0284-8630

Emma R Woodward http://orcid.org/0000-0002-6297-2855

D Gareth Evans http://orcid.org/0000-0002-8482-5784

\section{REFERENCES}

1 Zhang Y, Luo G, Li M, Guo P, Xiao Y, Ji H, Hao Y. Global patterns and trends in ovarian cancer incidence: age, period and birth cohort analysis. BMC Cancer 2019;19:984

2 Cancer Research UK. Ovarian cancer risk. Available: https://www.cancerresearchuk. org/health-professional/cancer-statistics/statistics-by-cancer-type/ovarian-cancer/riskfactors [Accessed 9 Apr 2020]

3 Arnold M, Rutherford MJ, Bardot A, Ferlay J, Andersson TM-L, Myklebust Tor Åge, Tervonen H, Thursfield V, Ransom D, Shack L, Woods RR, Turner D, Leonfellner S, Ryan S, Saint-Jacques N, De P, McClure C, Ramanakumar AV, Stuart-Panko H, Engholm G, Walsh PM, Jackson C, Vernon S, Morgan E, Gavin A, Morrison DS, Huws DW, Porter G, Butler J, Bryant H, Currow DC, Hiom S, Parkin DM, Sasieni P, Lambert PC, Møller B, Soerjomataram I, Bray F. Progress in cancer survival, mortality, and incidence in seven high-income countries 1995-2014 (ICBP SURVMARK-2): a population-based study. Lancet Oncol 2019;20:1493-505.

4 Alsop K, Fereday S, Meldrum C, deFazio A, Emmanuel C, George J, Dobrovic A, Birrer MJ, Webb PM, Stewart C, Friedlander M, Fox S, Bowtell D, Mitchell G. Brca mutation frequency and patterns of treatment response in BRCA mutation-positive women with ovarian cancer: a report from the Australian ovarian cancer Study Group. J Clin Oncol 2012;30:2654-63

5 Ryan NAJ, Glaire MA, Blake D, Cabrera-Dandy M, Evans DG, Crosbie EJ. The proportion of endometrial cancers associated with Lynch syndrome: a systematic review of the literature and meta-analysis. Genet Med 2019:21:2167-80.

6 Win AK, Jenkins MA, Dowty JG, Antoniou AC, Lee A, Giles GG, Buchanan DD, Clendenning M, Rosty C, Ahnen DJ, Thibodeau SN, Casey G, Gallinger S, Le Marchand L, Haile RW, Potter JD, Zheng Y, Lindor NM, Newcomb PA, Hopper JL, MacInnis RJ.
Prevalence and penetrance of major genes and polygenes for colorectal cancer. Cancer Epidemiol Biomarkers Prev 2017;26:404-12.

7 Barrow E, Robinson L, Alduaij W, Shenton A, Clancy T, Lalloo F, Hill J, Evans DG. Cumulative lifetime incidence of extracolonic cancers in Lynch syndrome: a report of 121 families with proven mutations. Clin Genet 2009;75:141-9.

8 Dominguez-Valentin M, Sampson JR, Seppälä TT, Ten Broeke SW, Plazzer J-P, Nakken S, Engel C, Aretz S, Jenkins MA, Sunde L, Bernstein I, Capella G, Balaguer F, Thomas H, Evans DG, Burn J, Greenblatt M, Hovig E, de Vos Tot Nederveen Cappel WH, Sijmons RH, Bertario L, Tibiletti MG, Cavestro GM, Lindblom A, Della Valle A, Lopez-Köstner F, Gluck N, Katz LH, Heinimann K, Vaccaro CA, Büttner R, Görgens H, Holinski-Feder E, Morak M, Holzapfel S, Hüneburg R, Knebel Doeberitz Mvon, Loeffler M, Rahner N, Schackert HK, Steinke-Lange V, Schmiegel W, Vangala D, Pylvänäinen K, RenkonenSinisalo L, Hopper JL, Win AK, Haile RW, Lindor NM, Gallinger S, Le Marchand L, Newcomb PA, Figueiredo JC, Thibodeau SN, Wadt K, Therkildsen C, Okkels H, Ketabi Z, Moreira L, Sánchez A, Serra-Burriel M, Pineda M, Navarro M, Blanco I, Green K, Lalloo F, Crosbie EJ, Hill J, Denton OG, Frayling IM, Rødland EA, Vasen H, Mints M, Neffa F, Esperon P, Alvarez K, Kariv R, Rosner G, Pinero TA, Gonzalez ML, Kalfayan P, Tjandra D, Winship IM, Macrae F, Möslein G, Mecklin J-P, Nielsen M, Møller P. Cancer risks by gene, age, and gender in 6350 carriers of pathogenic mismatch repair variants: findings from the prospective Lynch syndrome database. Genet Med 2020;22:15-25.

9 Vasen HF, Mecklin JP, Khan PM, Lynch HT. The International Collaborative group on hereditary non-polyposis colorectal cancer (ICG-HNPCC). Dis Colon Rectum 1991;34:424-5.

10 Vasen HF, Watson P, Mecklin JP, Lynch HT. New clinical criteria for hereditary nonpolyposis colorectal cancer (HNPCC, Lynch syndrome) proposed by the International Collaborative group on HNPCC. Gastroenterology 1999:116:1453-6.

11 Evaluation of Genomic Applications in Practice and Prevention (EGAPP) Working Group. Recommendations from the EGAPP Working group: genetic testing strategies in newly diagnosed individuals with colorectal cancer aimed at reducing morbidity and mortality from Lynch syndrome in relatives. Genet Med 2009;11:35-41.

12 Shia J. Evolving approach and clinical significance of detecting DNA mismatch repair deficiency in colorectal carcinoma. Semin Diagn Pathol 2015:32:352-61.

13 Bennett JA, Pesci A, Morales-Oyarvide V, Da Silva A, Nardi V, Oliva E. Incidence of mismatch repair protein deficiency and associated clinicopathologic features in a cohort of 104 ovarian endometrioid carcinomas. Am J Surg Pathol 2019;43:235-43.

14 Aysal A, Karnezis A, Medhi I, Grenert JP, Zaloudek CJ, Rabban JT. Ovarian endometrioid adenocarcinoma: incidence and clinical significance of the morphologic and immunohistochemical markers of mismatch repair protein defects and tumor microsatellite instability. Am J Surg Pathol 2012;36:163-72.

15 Ryan NAJ, Evans DG, Green K, Crosbie EJ. Pathological features and clinical behavior of Lynch syndrome-associated ovarian cancer. Gynecol Oncol 2017;144:491-5.

16 Ryan NAJ, Bolton J, McVey RJ, Evans DG, Crosbie EJ. BRCA and Lynch syndromeassociated ovarian cancers behave differently. Gynecol Oncol Rep 2017;22:108-9.

17 Barrow E, Evans DG, McMahon R, Hill J, Byers R. A comparative study of quantitative immunohistochemistry and quantum dot immunohistochemistry for mutation carrier identification in Lynch syndrome. J Clin Pathol 2011:64:208-14.

18 Parra-Herran C, Lerner-Ellis J, Xu B, Khalouei S, Bassiouny D, Cesari M, Ismiil N, Nofech-Mozes S. Molecular-Based classification algorithm for endometrial carcinoma categorizes ovarian endometrioid carcinoma into prognostically significant groups. Mod Pathol 2017:30:1748-59.

19 Pal T, Permuth-Wey J, Kumar A, Sellers TA. Systematic review and meta-analysis of ovarian cancers: estimation of microsatellite-high frequency and characterization of mismatch repair deficient tumor histology. Clin Cancer Res 2008:14:6847-54.

20 Murphy MA, Wentzensen N. Frequency of mismatch repair deficiency in ovarian cancer: a systematic review. Int J Cancer 2011:129:1914-22.

21 Leskela S, Romero I, Cristobal E, Pérez-Mies B, Rosa-Rosa JM, Gutierrez-Pecharroman A, Caniego-Casas T, Santón A, Ojeda B, López-Reig R, Palacios-Berraquero ML, García Ángel, Ibarra J, Hakim S, Guarch R, López-Guerrero JA, Poveda A, Palacios J. Mismatch repair deficiency in ovarian carcinoma: frequency, causes, and consequences. Am J Surg Pathol 2020;44:649-56.

22 Capoluongo E, Ellison G, López-Guerrero JA, Penault-Llorca F, Ligtenberg MJL, Banerjee $S$, Singer $C$, Friedman E, Markiefka B, Schirmacher $P$, Büttner $R$, van Asperen CJ, Ray-Coquard I, Endris V, Kamel-Reid S, Percival N, Bryce J, Röthlisberger B, Soong $\mathrm{R}$, de Castro DG. Guidance statement on BRCA1/2 tumor testing in ovarian cancer patients. Semin Oncol 2017;44:187-97

23 Vergote I, Banerjee S, Gerdes A-M, van Asperen C, Marth C, Vaz F, Ray-Coquard I, Stoppa-Lyonnet D, Gonzalez-Martin A, Sehouli J, Colombo N. Current perspectives on recommendations for BRCA genetic testing in ovarian cancer patients. Eur J Cancer 2016;69:127-34.

24 Crosbie EJ, Ryan NAJ, Arends MJ, Bosse T, Burn J, Cornes JM, Crawford R, Eccles D, Frayling IM, Ghaem-Maghami S, Hampel H, Kauff ND, Kitchener HC, Kitson SJ, Manchanda R, McMahon RFT, Monahan KJ, Menon U, Møller P, Möslein G, Rosenthal A, Sasieni P, Seif MW, Singh N, Skarrott P, Snowsill TM, Steele R, Tischkowitz M, Evans DG, Manchester International Consensus Group. The Manchester international consensus group recommendations for the management of gynecological cancers in Lynch syndrome. Genet Med 2019;21:2390-400. 